\title{
Woody Regeneration Response to Overstory Mortality Caused by the Hemlock Woolly Adelgid (Adelges tsugae) in the Southern Appalachian Mountains
}

\author{
Meghan L. Mulroy ${ }^{1,+}$, Eric J. Holzmueller ${ }^{2}$ and Michael A. Jenkins ${ }^{1, *}$ \\ 1 Department of Forestry and Natural Resources, Purdue University, 715 West State Street, \\ West Lafayette, IN 47907, USA \\ 2 Department of Forestry, Southern Illinois University, 1205 Lincoln Drive, Mail Code 4411, \\ Carbondale, IL 62901, USA \\ * Correspondence: jenkinma@purdue.edu \\ † Current address: Virginia Department of Forestry, 3909 Airline Boulevard, Chesapeake, VA 23321, USA.
}

Received: 27 June 2019; Accepted: 15 August 2019; Published: 21 August 2019

\begin{abstract}
Adelges tsugae Annand (hemlock woolly adelgid, HWA, an invasive insect native to Japan), which causes defoliation and death of Tsuga canadensis (L.) Carrière (eastern hemlock), was introduced to the United States in the early 1950s and has spread throughout much of the range of T. canadensis causing widespread mortality. In 2016 and 2017, we resampled long-term vegetation monitoring plots across five forest types (ecogroups) within Great Smoky Mountains National Park that contained T. canadensis in 2003 (prior to the spread of HWA within the park) to examine changes in the species composition and diversity of the regeneration layer. We hypothesized that compositional changes in the seedling and sapling strata would be driven primarily by the pre-HWA importance value of T. canadensis and relative dominance of Rhododendron maximum L. (rosebay rhododendron), and that species diversity metrics would differ across year depending on ecogroup and the relative dominance of R. maximum. Non-metric multi-dimensional scaling (NMDS) revealed that the seedling and sapling strata of plots with greater pre-HWA importance of T. canadensis and lower basal area of $R$. maximum generally exhibited greater compositional change between 2003 and 2017. Topo-edaphic variables were also significant in both NMDS ordinations and were associated with the distribution of multiple hardwood species. Species richness, evenness, and Shannon-Wiener diversity varied with strata following the loss of T. canadensis, with the degree and direction of change varying with the dominance of R. maximum.
\end{abstract}

Keywords: eastern hemlock; environmental gradients; ericaceous shrubs; gradient analysis; invasive insect; mixed hardwood forest; Rhododendron; species composition; Tsuga canadensis; understory

\section{Introduction}

With increased globalization and movement of material, humans have aided the invasion of forests by non-native pests and pathogens [1-3] that contribute to biodiversity loss [4] by altering ecosystem structure and function [5-7]. Over 450 non-native forest insects have been detected in the United States since 1635, sixteen of which are considered high-impact due to regulatory significance or documented negative effects on forest trees [6]. Invasive insects have both direct and indirect effects [7-9] that range in scale from the defoliation and death of individual trees, to long-term changes in forest composition, structure, productivity, and nutrient cycling that may cascade throughout the ecosystem $[8,9]$. In eastern North America, contemporary forests reflect a long and tragic history of 
non-native insects and pathogens functionally eliminating foundation tree species. The archetype example, Castanea dentata (Marshall) Borkh. (American chestnut), was the dominant tree species in the Appalachian Mountains prior to the introduction of the chestnut blight in the late 1800s, which led to its functional extinction [6]. Soon after the loss of C. dentata in the southern Appalachians, canopy gaps were filled by co-dominant species such as Quercus prinus L. (chestnut oak), Quercus rubra L. (northern red oak), and Acer rubrum L. (red maple) on dryer sites, and Tsuga canadensis (L.) Carrière and Halesia tetraptera Ellis (mountain silverbell) on more mesic sites [10,11]. By the late 1950s in Great Smoky Mountains National Park, approximately 30 years after C. dentata trees began to die, $41 \%$ of the resulting gaps were filled by Quercus spp. [11]. Similar results were observed elsewhere in the central and southern Appalachians [12]. However, as predicted by Keever [12], Carya spp. Nutt. (hickory species) became a co-dominant in some parts of the southern Appalachians by the late 1960s and early 1970s [10]. The relative importance of various Quercus and Carya species varied with elevation [11], suggesting that edaphic conditions played an important role in shaping forests following the loss of C. dentata [10].

Currently, eastern forests are facing the loss of yet another foundation species as T. canadensis is disappearing throughout much of its range due to the introduction of Adelges tsugae Annand (hemlock woolly adelgid; HWA), a host-specific and highly virulent invasive insect [6,8]. Similar to the chestnut blight, HWA eliminates T. canadensis from forests over a relatively short time scale [11,13], rapidly changing the microclimate of the forest floor and creating growing space across multiple strata. Under similar conditions, Woods and Shanks [11] identified three processes responsible for the replacement of $C$. dentata in forest overstories: closure of the canopy by adjacent dominant or co-dominant trees, growth of existing saplings, and establishment and growth of seedlings. It remains to be seen, however, the degree to which these processes are affecting the composition of forests in the southern Appalachians following the loss of T. canadensis.

HWA was introduced to the eastern United States in the 1950s in Richmond, Virginia [14]. The insect feeds on the xylem ray parenchyma cells, depleting stored nutrients within the tree. The stress that results from depleted nutrient stores and toxins in HWA salivary secretions causes severe defoliation and eventual death of infested trees [15]. Mortality can occur in as little as four years; however, trees may survive longer under favorable conditions such as low winter temperatures, which reduces the density of HWA populations, and adequate summer water availability, which improves tree vigor $[13,16]$.

Tsuga canadensis typically grows in cool, humid habitats extending from the southern Appalachian Mountains to the Great Lakes and into Canada. In the southern Appalachians, the species is typically found in mixed stands on slopes and in drainages at elevations between 610 and $1520 \mathrm{~m}$, often with a dense understory of R. maximum [6,17]. Following the functional loss of C. dentata and decades of fire suppression, T. canadensis expanded its distribution within forests of the southern Appalachians and became a dominant species in the understories of oak-hickory forests $[18,19]$. As a foundation species, loss of T. canadensis as a result of HWA will likely result in significant short and long-term changes in eastern forests $[6,8,20]$.

In the northeastern United States, where T. canadensis typically occurs in pure stands $[6,16,21-24]$, HWA-induced mortality of T. canadensis has resulted in increased density of early-mid seral hardwood species such as Betula lenta L. (black birch), A. rubrum (red maple), Prunus serotina Ehrh. (black cherry) and Quercus spp. (oak species; $[23,24]$ ). Increased subcanopy tree and seedling density have also been observed, as well as increased species richness and abundance of invasive plants [21,23-25].

HWA was first identified in Great Smoky Mountain National Park (GSMNP) in 2002 and by 2006 had spread to all watersheds within the park [26]. Early mortality of T. canadensis (five-to-six years after HWA arrived) was greater in the understory than in the overstory, representing a bottom-up elimination of the species [27]. Overall, T. canadensis decline did not differ among ecogroups (a mesoscale classification unit consisting of multiple vegetation associations); however, overstory T. canadensis trees fared worse in floodplain forests compared to other ecogroups [27]. Within the central Appalachians, 
modeling of HWA-induced mortality predicted that within 20 years of infestation, hemlock-dominated forests will cease to exist and less than two percent of the initial living T. canadensis basal area (BA) will remain [28].

Beyond the decline of $T$. canadensis, no significant changes in forest composition were identified five-to-six years after infestation in GSMNP [27]. In addition to the short time span after the arrival of HWA, the lack of significant community change may have resulted from high $R$. maximum cover continuing to shade the forest floor and sequester soil nutrients after the mortality of T. canadensis $[29,30]$. Rhododendron maximum cover increased in the southern Appalachians in the 1930s following the loss of C. dentata $[19,31]$, and in the contemporary forest following HWA-induced mortality in the region [30]. Tsuga canadensis, however, is widely distributed in southern Appalachians, and some forests have experienced increased growth of co-occurring hardwood species, particularly in areas without heavy cover of R. maximum [30].

The infestation of HWA in the southern Appalachians is well into its second decade and near complete mortality of $T$. canadensis has been observed, with the exception of a limited number of trees that have been chemically treated. As forests react to this loss of a foundation species, long-term plot data can begin to elucidate changes in forest composition and structure across the range of forest types in which T. canadensis historically occurred. Examining these changes across multiple strata of woody vegetation distributed across multiple topo-edaphic gradients allows the prediction of future successional development.

In order to understand how HWA-induced mortality of T. canadensis has affected forests of the southern Appalachian Mountains, we examined how the composition and diversity of woody vegetation strata have changed across different forest ecogroups. We used a data set garnered from a network of plots distributed across the eastern half of Great Smoky Mountains National Park (Figure 1) prior to T. canadensis mortality and sampled over a 14-year period after infestation and mortality. These data allowed us to examine over a decade of changes in vegetation communities across a wide range of environmental conditions. As such, our study provided a valuable assessment of long-term change in forests across a complex landscape in response to exogenous disturbance resulting from a highly destructive non-native insect.

We elucidated how environmental gradients (based on topo-edaphic variables) are related to community composition and how these gradients influenced changes in woody regeneration following the loss of T. canadensis. We hypothesized that changes in the composition of the seedling and sapling strata were driven primarily by the pre-HWA importance value of $T$. canadensis and relative dominance of $R$. maximum. We further hypothesized that the distribution of individual species will be influenced by topo-edaphic variables on sites with lower dominance of R. maximum, and heavy dominance of R. maximum will reduce the influence of these variables. Finally, we hypothesized that species diversity metrics will differ between years and across ecogroups following the loss of T. canadensis based upon the dominance of R. maximum. Understanding these changes will provide valuable information about how the post-HWA development of these forests may diverge across environmental and structural gradients. This information will help guide the assessment of future threats to forests resulting from non-native insects and pathogens.

\section{Methods}

\subsection{Study Area}

Located in the southern Appalachian Mountains of eastern Tennessee and western North Carolina (Figure 1), Great Smoky Mountain National Park (GSMNP) is home to a diverse assemblage of plant species and is an internationally renowned center of biodiversity [32]. In response to widespread logging in the southern Appalachians, the Park was established in 1934 to protect remaining primary forest, which comprises $20 \%$ of the park's 212,000 ha [32]. Today, GSMNP is the most visited National Park in the United States. Elevation within the park ranges from 267 to $2025 \mathrm{~m}$ and terrain is generally 
rugged [32]. Annual precipitation is elevation dependent and ranges from 140 to $200 \mathrm{~cm}$ per year [31]. Parent material is primarily composed of metamorphic sandstone, quarzites, and slates, with smaller pockets of limestone [32-34].

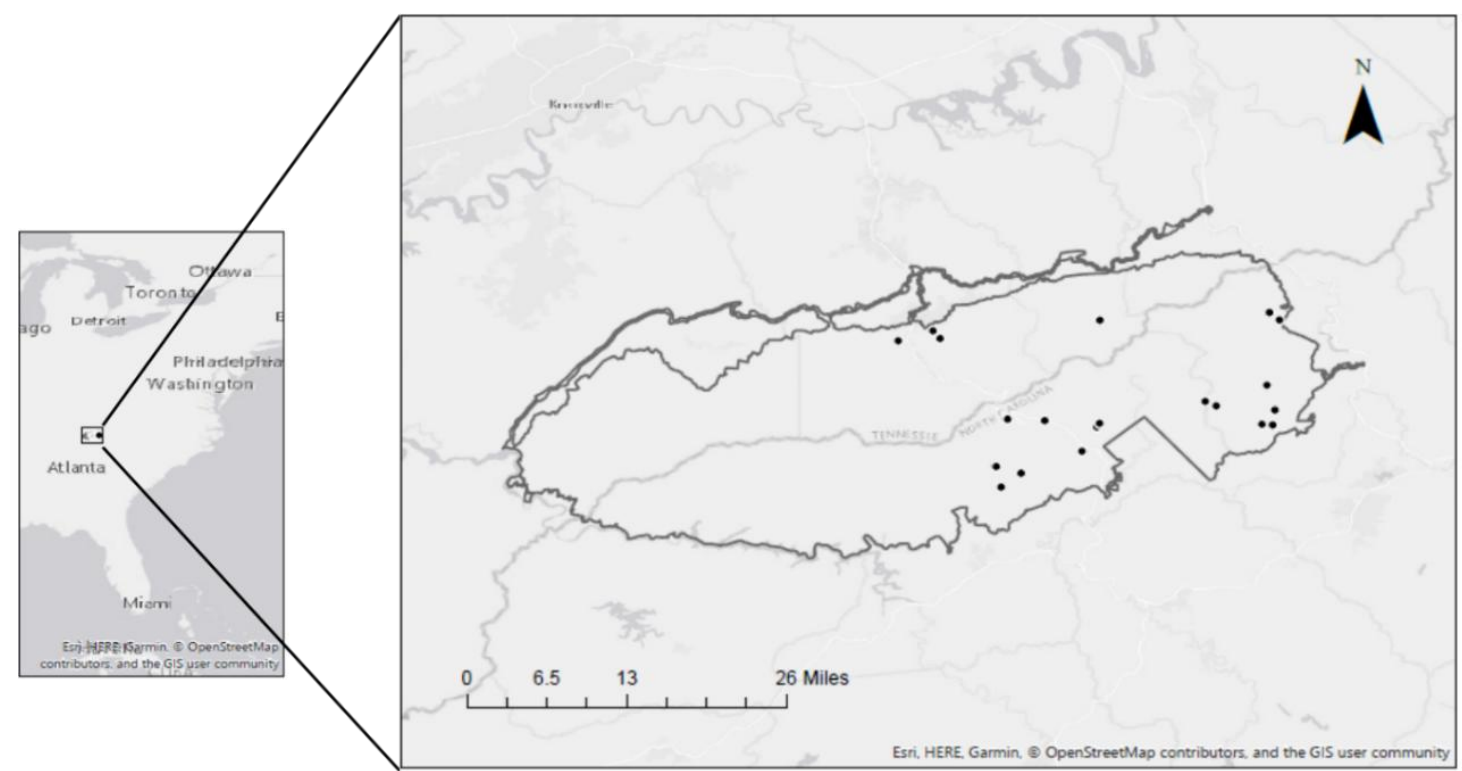

Figure 1. Map of Great Smoky Mountains National Park showing locations of vegetation monitoring plots sampled in 2003 and 2016/2017. Plots were established in clusters of three and some individual plots are not distinguishable at this scale.

Over 1300 native plant species are found within the park, comprising 79 distinct plant communities [32,35], which can be grouped into 11 broader ecogroups based on species composition, landscape position, and shared management issues [32,35]. Prior to HWA infestation, T. canadensis occurred across a wide variety of forest ecogroups within the park and was dominant or co-dominant in four ecogroups (Montane Alluvial Forests, Cove Forests, Hemlock Forests, and Spruce-fir Forests). GSMNP was home to stands containing some of the oldest and largest T. canadensis trees in eastern North America [32,34,36], however, living T. canadensis trees today are primarily limited to conservation areas such as old growth forest, as well as highly visited areas in the front country, road sides, and backcountry campgrounds $[26,37,38]$ where trees have been treated with the neonicotinoid imidacloprid, a systemic insecticide. In addition, two predatory beetles (Sasajscymnus spp. and Laricobius spp.) have been released as biocontrol agents, but have yet to slow the advance of HWA.

\subsection{Vegetation Sampling}

Data were collected from vegetation monitoring plots that were established as part of the National Park Service Inventory and Monitoring Program using a clustered stratified random sampling design [39]. In 2016 and 2017, we resampled plots established in five ecogroups [34]: acid hardwood forest $(n=3)$, hemlock forest $(n=5)$, montane cove forest $(n=13)$, montane oak-hickory forest $(n=3)$, and northern hardwood forest $(n=6)$. In 2016/2017, we also resampled three plots located in floodplain and montane cove ecogroup forests that had been treated with the insecticide imidacloprid. These plots contained healthy T. canadensis trees and were placed in the "treated" category for analysis. A total of 33 plots were resampled in 2016 and 2017. All plots were established and initially sampled in 2003 prior to widespread HWA infestation and were resampled in both 2008/2009 and 2016/2107 [27-29]. During the 2008/2009 sampling, HWA was observed on all plots [27]. Data collected during the 2003 and 2016/2017 sample dates were used for analysis. Because only two plots were sampled in 2016 (vs. 31 in 2017), henceforth we refer to the most recent resampling as "2017". 
Data collection followed the Great Smoky Mountain National Park Vegetation Monitoring Protocol [39]. Each 0.1 ha $(20 \mathrm{~m} \times 50 \mathrm{~m})$ plot was divided into ten $100 \mathrm{~m}^{2}$ modules. Woody vegetation was sampled in three strata: overstory trees, saplings, and seedlings. Across all modules, overstory trees ( $>1.4 \mathrm{~m}$ in height and $\geq 10 \mathrm{~cm} \mathrm{DBH})$ were identified to species and measured for diameter at breast height (DBH; $1.4 \mathrm{~m}$ ). Saplings (woody stems $\geq 1.4 \mathrm{~m}$ in height, but $<10 \mathrm{~cm} \mathrm{DBH}$ ) were tallied across all ten modules by species into four size classes (0-0.9 cm DBH, $1.0-2.4 \mathrm{~cm} \mathrm{DBH}, 2.5-4.9 \mathrm{~cm} \mathrm{DBH}$, $5.0-9.9 \mathrm{~cm} \mathrm{DBH})$. When high density of woody stems prohibited the sampling of all ten modules, tallies were performed in three to five randomly selected modules. Seedlings (woody stems $<1.4 \mathrm{~m}$ in height) were tallied by species within $10 \mathrm{~m}^{2}$ subplots nested within four modules in a $2 \times 2$ arrangement [39].

Soil samples were collected to a depth of approximately $10 \mathrm{~cm}$ from the center of every other module, resulting in five samples per plot. These five samples were pooled into a single plot-level sample for testing. Samples were stored in a freezer until they were sent to Waypoint Analytical, Memphis, TN, USA (formerly known as A\&L Analytical Laboratories, Inc., Memphis, TN, USA) following collection in both 2003 and 2017. Soil samples were analyzed for cation exchange capacity (CEC), $\mathrm{pH}$, and the concentration of potassium $(\mathrm{K})$, calcium $(\mathrm{Ca})$, phosphorus $(\mathrm{P})$, and magnesium $(\mathrm{Mg})$ using Mehlich III extracting solution [40]. Soil organic matter (OM) was determined using the loss on ignition technique.

\subsection{Data Preparation}

We calculated the relative densities of seedlings and saplings by species $(\mathrm{RD}=$ density of species $i$ density of all species) and the importance value of overstory trees by species [IV $=$ (relative density + relative basal area)/2) $\times 100$ ] for each ecogroup for both 2003 and 2017. To quantify changes in overstory structure, we calculated total stand basal area $\left(\mathrm{m}^{2} / \mathrm{ha}\right)$ for each ecogroup in both 2003 and 2017. Species richness (S), Shannon-Wiener Diversity $\left(\mathrm{H}^{\prime}\right)$, and species evenness (E) were calculated for both the seedling and sapling strata [41]. Prior to analyses, all data were examined for assumptions of normality by examining the distribution of residuals using normal QQ plots and using the Shapiro-Wilk test of normality, and equal variance by examining residual plots. These analyses were done using the packages "stats" and "graphics" in R [42]. All data meet assumptions, with the exception of seedling E, which varied slightly from a normal distribution. Squaring E improved the distribution, but did not affect the results of the analysis; therefore, we used the untransformed data in the analysis.

Aspect and slope were used to calculate the total potential incident radiation (RAD) for each plot by accounting for the varying effect of aspect at different slopes [43]: $\ln (\mathrm{RAD})=-1.236+1.350 \cos (\mathrm{L})$ $\times \cos (\mathrm{S})-1.376 \cos (\mathrm{A}) \times \sin (\mathrm{S}) \times \sin (\mathrm{L})-0.331 \sin (\mathrm{L}) \times \sin (\mathrm{S})+0.375 \sin (\mathrm{A}) \times \sin (\mathrm{S})$; where $\mathrm{RAD}$ is potential direct incident radiation, $\mathrm{S}$ is slope, $\mathrm{L}$ is latitude, and $\mathrm{A}$ is folded aspect $(\mathrm{A}=180-$ |Aspect 225|). Slope, latitude, and folded aspect were all transformed to radians prior to calculations.

\subsection{Statistical Analysis}

\subsubsection{Changes in Overstory Basal Area}

To quantify changes in overstory structure, we compared total stand basal area between 2003 and 2017 with a general linear mixed model using the R packages "lme4" and "ImerTest" [44-46]. Ecogroup and sampling year were treated as fully crossed fixed factors and plot was included as a random factor to account for the lack of independence due to the repeated measures design of the study [46]. The interaction term between year and ecogroup was not included due to lack of significant difference in AIC values. We, therefore, selected the more parsimonious model. Treated plots were excluded from this analysis, but changes in basal area on treated plots are presented for comparison (Table 1). 
Table 1. Total basal area $\left(\mathrm{m}^{2} \mathrm{ha}^{-1}\right.$; mean $\left.\pm \mathrm{SE}\right)$ across ecogroups and chemically treated plots in 2003 and 2016/2017 (shown as 2017). Treated plots were not included in the calculations of total mean basal area across all ecogroups.

\begin{tabular}{lccccccc}
\hline Year & $\begin{array}{c}\text { Acid } \\
\text { Hardwood } \\
(\boldsymbol{n}=\mathbf{3})\end{array}$ & $\begin{array}{c}\text { Hemlock } \\
(\boldsymbol{n}=\mathbf{5})\end{array}$ & $\begin{array}{c}\text { Montane } \\
\text { Cove } \\
(\boldsymbol{n}=\mathbf{1 3})\end{array}$ & $\begin{array}{c}\text { Montane } \\
\text { Oak-Hickory } \\
(\boldsymbol{n}=\mathbf{3})\end{array}$ & $\begin{array}{c}\text { Northern } \\
\text { Hardwood } \\
(\boldsymbol{n}=\mathbf{6})\end{array}$ & $\begin{array}{c}\text { Total } \\
(\boldsymbol{n}=\mathbf{3 0})\end{array}$ & $\begin{array}{c}\text { Treated } \\
(\boldsymbol{n}=\mathbf{3})\end{array}$ \\
\hline 2003 & $31.3 \pm 4.6$ & $33.7 \pm 1.5$ & $31.4 \pm 2.2$ & $35.4 \pm 6.0$ & $31.6 \pm 5.8$ & $32.2 \pm 1.5$ & $31.8 \pm 2.8$ \\
2017 & $31.0 \pm 2.1$ & $28.8 \pm 5.0$ & $28.2 \pm 2.4$ & $27.0 \pm 4.8$ & $24.9 \pm 3.6$ & $27.8 \pm 1.5$ & $34.6 \pm 1.7$ \\
\hline
\end{tabular}

\subsubsection{Changes in Species Composition}

We used non-metric multidimensional scaling (NMDS) of relative density data to examine changes in species composition across environmental gradients within the seedling and sapling strata. Analyses were conducted with the metaMDS procedure in the VEGAN package for community ecology using the Bray-Curtis dissimilarity matrix [47]. Data were transformed using square root and Wisconsin double standardization to increase the influence of rare species in differentiating between plots, and species with fewer than three occurrences across all plots in both 2003 and 2017 were excluded from analysis. The ordination procedure used random starting points to find convergent solutions. A maximum of 100 iterations were permitted. Stress of the ordination was used to determine the number of axes in the final solution. Monte Carlo randomization procedure was used to assess if the axes produced were stronger than expected by chance [41]. NMDS ordinations were performed on 99 data sets in which species values had been randomized. P-values were calculated as the proportion of runs for which the stress resulting from the randomized ordination was less than the observed stress. For all ordinations, the $\mathrm{p}$-value indicated that the axes produced were stronger than expected by chance.

To examine correlations with environmental variables, we used the ENVFIT procedure in the VEGAN package [47]. This function allowed us to fit environmental vectors and mean factor values (mean ordination scores for categorical variables) onto the resulting NMDS ordination scores derived for individual points (plots) and determine correlations with the ordination. The projections of points onto vectors have maximum correlation with corresponding environmental variables, and the factors show the averages of factor levels. Significance of the correlations was assessed through permutation tests [47] with $\alpha=0.05$. Environmental variables with $p<0.1$ were displayed in the ordination figures. Total RAD, CEC, pH, OM, concentration (ppm) of $\mathrm{P}, \mathrm{Ca}, \mathrm{K}$, and $\mathrm{Mg}$, elevation, slope, and pre-HWA T. canadensis IV were used in analysis across both woody vegetation strata. For the seedling strata the BA of R. maximum in 2003, sapling density (all species combined), and Rubus spp. L. (blackberry) percent cover were also included as environmental variables. Ecogroup was also included as a factor and fit to both ordinations.

\subsubsection{Changes in Species Diversity}

Changes in species richness, evenness, and diversity following HWA infestation and subsequent T. canadensis mortality were analyzed across the seedling and sapling strata with general linear mixed models using the R packages "lme4" and "ImerTest" [44-46]. Ecogroup and sampling year were treated as fully crossed fixed factors and R. maximum BA was also included in the analysis as a linear covariate in both the seedling and sapling strata analyses when analysis indicted that the inclusion of this factor significantly lowered the AIC value. If there was no significant difference between model AIC values, we selected the more parsimonious model. When the covariate was included, if initial analysis indicated that a significant interaction existed with $R$. maximum BA, the covariate was crossed with ecogroup and year. Plot was included as a random factor to account for the lack of independence due to the repeated measures design of the study [46]. If a significant difference $(\alpha=0.05)$ was detected among ecogroups or year, post-hoc Tukey tests $(\alpha=0.05)$ were performed to determine differences between ecogroups and year using the "lsmeans" package in R [48]. All numerical variables were standardized prior to analysis. 


\section{Results}

\subsection{Overstory Basal Area and Species Importance}

Overstory basal area declined between years across ecogroups ( $\mathrm{F}=6.87, p=0.014$; Table 1$)$, ranging from no change in acid cove forests to a $24 \%$ decline in montane oak-hickory forests $\left(35.4 \pm 6.0 \mathrm{~m}^{2} \mathrm{ha}^{-1}\right.$ in 2003 to $27.0 \pm 4.8 \mathrm{~m}^{2} \mathrm{ha}^{-1}$ in 2017). Changes in basal area did not differ significantly with ecogroup $(\mathrm{F}=0.14, p=0.97)$. The IV of $T$. canadensis in 2003 varied across ecogroups, ranging from $4.7 \pm 2.1$ in acid hardwood forest to $33.9 \pm 11.2$ in hemlock forests (Figure 2a; Table 2). As expected, mortality from HWA greatly reduced the importance of T. canadensis in the overstory (Figure 2a), with reductions ranging from $70 \%$ in acid hardwood forests $(4.7 \pm 1.4$ in 2003 to $1.4 \pm 1.1$ in 2017$)$ to $96 \%$ in montane cove forests $(23.2 \pm 3.5$ to $0.9 \pm 0.7)$. Across ecogroups, no single species increased greatly in IV with the decline in T. canadensis IV. Rather, a suite of hardwood species, including Betula alleghaniensis Britton (yellow birch), B. lenta, Magnolia fraseri Walter (Fraser magnolia) and A. rubrum displayed increased importance with the loss of T. canadensis (Table 2).
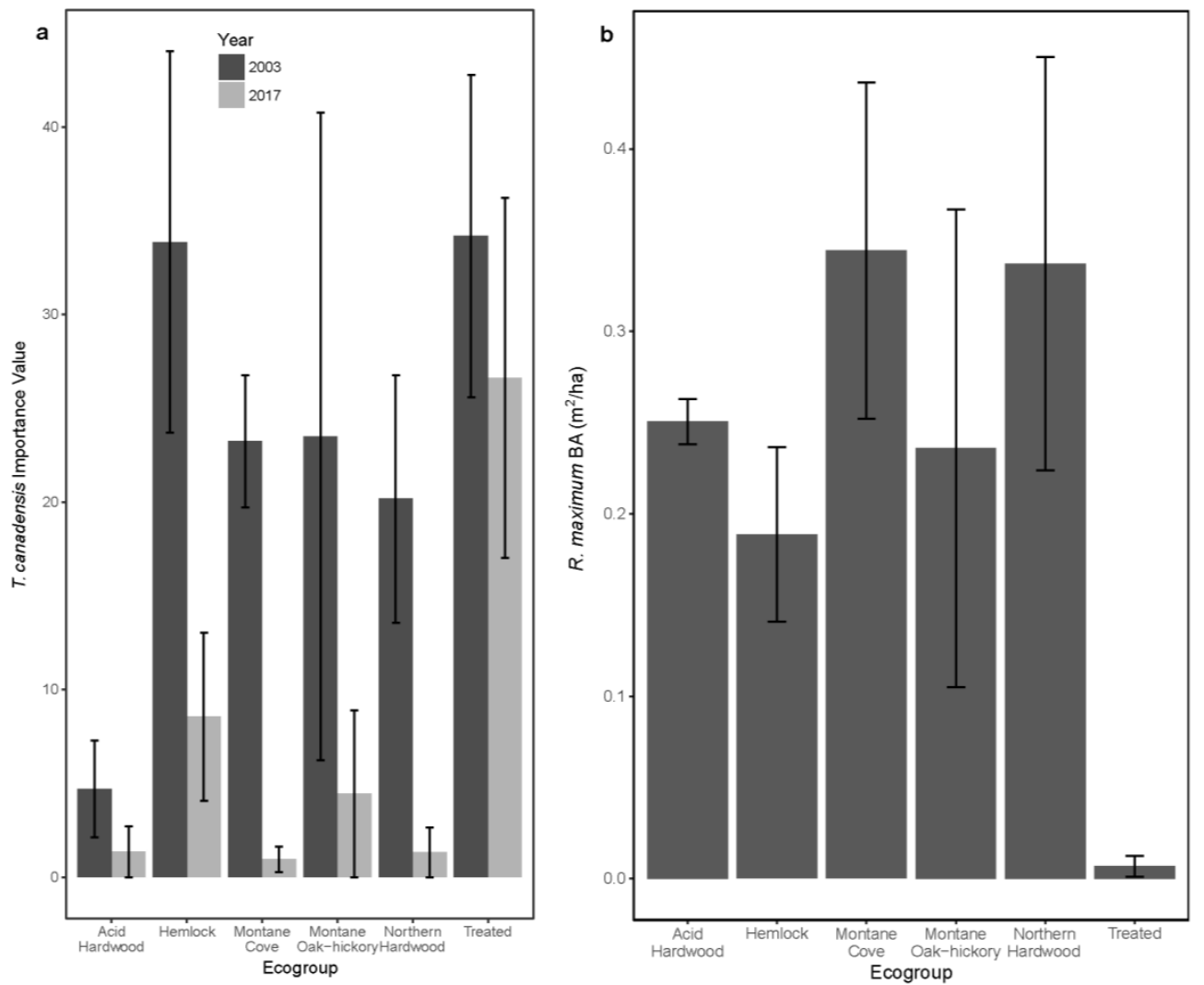

Figure 2. (a) Mean $( \pm$ SE) T. canadensis IV in 2003 and 2017 by ecogroup; (b) Mean $( \pm$ SE) basal area of R. maximum in 2003 by ecogroup.

\subsection{Seedling Species Composition}

NMDS of the seedling stratum resulted in a three axes solution with a final stress of 0.159 after 72 runs. The ordination had a linear $\mathrm{R}^{2}$ of 0.835 . Rhododendron maximum $\mathrm{BA}\left(\mathrm{R}^{2}=0.52, p=0.001\right)$ and sapling density $\left(\mathrm{R}^{2}=0.47, p=0.001\right)$ had the strongest correlations with seedling species composition (Figure 3a, Table 3). CEC $\left(\mathrm{R}^{2}=0.17, p=0.010\right), \mathrm{pH}\left(\mathrm{R}^{2}=0.16, p=0.014\right), \mathrm{P}\left(\mathrm{R}^{2}=0.18, p=0.008\right)$, $\mathrm{Ca}\left(\mathrm{R}^{2}=0.37, p=0.001\right), \mathrm{Mg}\left(\mathrm{R}^{2}=0.40, p=0.001\right)$, elevation $\left(\mathrm{R}^{2}=0.19, p=0.006\right), \operatorname{RAD}\left(\mathrm{R}^{2}=0.25\right.$, $p=0.003)$, pre-HWA T. canadensis IV $\left(\mathrm{R}^{2}=0.23\right.$ and $\left.p=0.003\right)$, and percent $R u b u s$ spp. cover $\left(\mathrm{R}^{2}=0.18\right.$, $p=0.004$ ) were also significantly correlated with the ordination (Figure 3a, Table 3). 
Table 2. Importance value (IV; mean \pm SE) of selected species across ecogroups and chemically treated plots in 2003 and 2016/17 (shown as 2017). Only species with a mean IV greater than one calculated across all ecogroups and treated plots are included.

\begin{tabular}{|c|c|c|c|c|c|c|c|c|c|c|c|c|}
\hline \multirow[t]{2}{*}{ Species } & \multicolumn{2}{|c|}{$\begin{array}{l}\text { Acid Hardwood } \\
\quad(n=3)\end{array}$} & \multicolumn{2}{|c|}{$\begin{array}{l}\text { Hemlock } \\
\quad(n=5)\end{array}$} & \multicolumn{2}{|c|}{$\begin{array}{l}\text { Montane Cove } \\
\quad(n=13)\end{array}$} & \multicolumn{2}{|c|}{$\begin{array}{l}\text { Montane Oak-Hickory } \\
\qquad(n=3)\end{array}$} & \multicolumn{2}{|c|}{$\begin{array}{l}\text { Northern Hardwood } \\
\qquad(n=6)\end{array}$} & \multicolumn{2}{|c|}{$\begin{array}{l}\text { Treated } \\
(n=3)\end{array}$} \\
\hline & 2003 & 2017 & 2003 & 2017 & 2003 & 2017 & 2003 & 2017 & 2003 & 2017 & 2003 & 2017 \\
\hline Acer pensylvanicum & $2.5 \pm 1.3$ & $3.2 \pm 1.8$ & $0.6 \pm 0.6$ & $2.0 \pm 1.3$ & $2.4 \pm 1.7$ & $2.0 \pm 1.7$ & $0.6 \pm 0.6$ & 0 & $2.9 \pm 2.3$ & $4.5 \pm 3.9$ & 0 & 0 \\
\hline Acer saccharum & 0 & 0 & 0 & $2.2 \pm 2.2$ & 0 & $1.0 \pm 0.4$ & $0.6 \pm 0.6$ & $1.3 \pm 1.3$ & $6.2 \pm 3.4$ & $8.6 \pm 4.1$ & $2.2 \pm 1.6$ & $2.3 \pm 2.3$ \\
\hline Amelanchier laevis & $7.4 \pm 6.0$ & $6.8 \pm 5.6$ & 0 & 0 & $0.6 \pm 0.4$ & $0.1 \pm 0.1$ & $0.6 \pm 0.6$ & $0.7 \pm 0.7$ & $0.6 \pm 0.6$ & $0.7 \pm 0.7$ & 0 & 0 \\
\hline Betula alleghaniensis & $13.0 \pm 9.7$ & $14.0 \pm 10.6$ & $5.4 \pm 3.4$ & $4.0 \pm 2.5$ & $9.6 \pm 3.5$ & $14.3 \pm 5.1$ & $1.3 \pm 1.3$ & $4.4 \pm 4.4$ & $18.4 \pm 7.9$ & $22.5 \pm 8.5$ & $0.4 \pm 0.4$ & $0.5 \pm 0.5$ \\
\hline Betula lenta & $5.0 \pm 0.2$ & $2.6 \pm 1.1$ & $10.3 \pm 2.7$ & $20.7 \pm 6.0$ & $12.4 \pm 5.0$ & $15.6 \pm 5.4$ & $5.2 \pm 3.5$ & $6.4 \pm 3.9$ & $3.5 \pm 1.8$ & $4.7 \pm 2.7$ & $3.8 \pm 1.3$ & $5.6 \pm 2.2$ \\
\hline Fagus grandifolia & $5.3 \pm 4.3$ & $8.3 \pm 6.8$ & $0.3 \pm 0.3$ & $0.4 \pm 0.4$ & $5.5 \pm 2.3$ & $4.8 \pm 2.2$ & 0 & 0 & $12.5 \pm 4.4$ & $13.4 \pm 3.2$ & $0.8 \pm 0.8$ & $1.6 \pm 0.9$ \\
\hline Halesia tetraptera & $1.8 \pm 1.5$ & 0 & $3.5 \pm 1.1$ & $5.7 \pm 3.0$ & $5.0 \pm 1.3$ & $6.2 \pm 1.6$ & $0.6 \pm 0.6$ & $0.6 \pm 0.6$ & $7.3 \pm 3.4$ & $11.3 \pm 5.1$ & $0.4 \pm 0.4$ & $0.5 \pm 0.5$ \\
\hline Liriodendron tulipifera & 0 & 0 & $4.4 \pm 1.4$ & $8.2 \pm 2.4$ & $1.9 \pm 1.0$ & $2.8 \pm 1.5$ & $2.0 \pm 2.0$ & $4.4 \pm 4.4$ & 0 & 0 & $15.0 \pm 5.9$ & $18.9 \pm 8.5$ \\
\hline Magnolia fraseri & $5.4 \pm 4.4$ & $8.2 \pm 6.7$ & $1.6 \pm 1.0$ & $2.2 \pm 1.6$ & $2.1 \pm 1.1$ & $4.5 \pm 1.8$ & $1.9 \pm 1.9$ & $1.3 \pm 1.3$ & $1.6 \pm 0.8$ & $3.0 \pm 1.3$ & 0 & 0 \\
\hline Nyssa sylvatica & $3.6 \pm 2.9$ & $2.5 \pm 2.1$ & $0.3 \pm 0.3$ & $0.3 \pm 0.3$ & $1.2 \pm 0.6$ & $1.2 \pm 0.8$ & $1.7 \pm 1.7$ & $1.7 \pm 1.7$ & $0.3 \pm 0.3$ & $0.6 \pm 0.6$ & $1.3 \pm 1.3$ & $2.1 \pm 2.1$ \\
\hline Oxydendrum arboreum & $6.3 \pm 5.1$ & $5.0 \pm 4.1$ & $4.4 \pm 3.3$ & $4.5 \pm 3.2$ & $4.5 \pm 2.0$ & $6.3 \pm 3.0$ & $9.0 \pm 2.5$ & $13.1 \pm 0.6$ & 0 & 0 & $5.4 \pm 3.7$ & $4.7 \pm 3.3$ \\
\hline Picea rubens & $16.0 \pm 8.9$ & $12.4 \pm 5.9$ & 0 & 0 & $2.9 \pm 2.8$ & $3.8 \pm 3.6$ & 0 & 0 & 0 & 0 & 0 & 0 \\
\hline Pinus strobus & 0 & 0 & $4.6 \pm 4.6$ & $4.4 \pm 4.4$ & $0.8 \pm 0.8$ & $0.8 \pm 0.8$ & 0 & 0 & 0 & 0 & 0 & 0 \\
\hline Quercus prinus & $6.1 \pm 4.1$ & $4.5 \pm 2.4$ & $1.3 \pm 0.9$ & $1.9 \pm 1.6$ & $2.6 \pm 1.4$ & $2.7 \pm 1.5$ & $12.8 \pm 9.6$ & $11.8 \pm 10.1$ & 0 & 0 & $0.4 \pm 0.4$ & $0.5 \pm 0.5$ \\
\hline Quercus rubra & $3.7 \pm 3.0$ & $3.4 \pm 2.8$ & $2.2 \pm 1.2$ & $1.7 \pm 0.8$ & $2.3 \pm 0.9$ & $2.7 \pm 1.4$ & $2.5 \pm 2.5$ & $2.0 \pm 2.0$ & $0.3 \pm 0.3$ & $0.6 \pm 0.6$ & $0.8 \pm 0.4$ & $1.0 \pm 0.5$ \\
\hline $\begin{array}{l}\text { Rhododendron } \\
\text { maximum }\end{array}$ & $1.6 \pm 0.7$ & $1.3 \pm 0.5$ & $1.2 \pm 0.6$ & $3.6 \pm 2.0$ & $4.6 \pm 2.4$ & $6.6 \pm 2.2$ & $5.1 \pm 5.1$ & $5.2 \pm 5.2$ & $3.4 \pm 1.4$ & $8.1 \pm 3.6$ & 0 & 0 \\
\hline Tsuga canadensis & $4.7 \pm 2.1$ & $1.4 \pm 1.1$ & $33.9 \pm 11.2$ & $8.6 \pm 4.5$ & $23.2 \pm 3.5$ & $0.9 \pm 0.7$ & $23.5 \pm 17.3$ & $4.4 \pm 4.4$ & $20.2 \pm 6.6$ & $1.3 \pm 1.3$ & $34.2 \pm 8.6$ & $26.6 \pm 9.6$ \\
\hline
\end{tabular}


Table 3. Correlation coefficients of environmental variables with NMDS ordination results for the seedling and sapling strata.

\begin{tabular}{ccccc}
\hline \multirow{2}{*}{ Environmental Variable } & \multicolumn{2}{c}{ Seedling } & \multicolumn{2}{c}{ Sapling } \\
\cline { 2 - 5 } & $\mathbf{R}^{\mathbf{2}}$ & $\boldsymbol{p}$ & $\mathbf{R}^{\mathbf{2}}$ & $\boldsymbol{p}$ \\
\hline RAD & 0.245 & 0.003 & 0.320 & 0.001 \\
CEC & 0.168 & 0.010 & 0.007 & 0.819 \\
pH & 0.160 & 0.014 & 0.036 & 0.363 \\
OM & 0.033 & 0.555 & 0.083 & 0.081 \\
P (ppm) & 0.182 & 0.008 & 0.025 & 0.455 \\
Ca (ppm) & 0.372 & 0.001 & 0.059 & 0.156 \\
K (ppm) & 0.043 & 0.471 & 0.081 & 0.086 \\
Mg (ppm) & 0.395 & 0.001 & 0.082 & 0.087 \\
Elevation & 0.185 & 0.006 & 0.103 & 0.048 \\
Slope (\%) & 0.075 & 0.193 & 0.102 & 0.046 \\
Pre-HWA T. canadensis IV & 0.230 & 0.003 & 0.196 & 0.003 \\
R. maximum basal area & 0.524 & 0.001 & - & - \\
Sapling density & 0.468 & 0.001 & - & - \\
Rubus spp. percent cover & 0.178 & 0.004 & - & - \\
Ecogroup & 0.125 & 0.074 & 0.303 & 0.001 \\
\hline
\end{tabular}

The majority of seedling species were positively associated with RAD and pre-HWA T. canadensis IV and negatively associated with R. maximum BA and total sapling density (Figure 3a). Viburnum lantanoides (hobblebush), Euonymus americanus L. (strawberry bush), Euonymus obovatus Nutt. (running strawberry bush), Vitis spp. (grape species), Aesculus flava Aiton (yellow buckeye), Fraxinus americana L. (white ash), and Leucothoe fontanesiana (Steud.) Sleumer (highland doghobble), were positively correlated with soils with greater $\mathrm{pH}$, and $\mathrm{CEC}$, and $\mathrm{P}$, as well as greater cover of Rubus species. Acer saccharum Marshall (sugar maple) displayed a strong positive correlation with pre-HWA T. canadensis IV. Picea rubens Sarg. (red spruce), Acer spicatum Lam. (mountain maple), and B. alleghaniensis were strongly positively correlated with sapling density, indicating that they tended to be found on plots with a dense regeneration layer. Finally, Ilex montana Torr. \& A. Gray ex A. Gray (mountain holly) was positively correlated with $R$. maximum BA (Figure 3a). Within ecogroups, changes in seedling species composition between sampling dates did not exhibit clear trends in the ordination, nor did ecogroups exhibit significant correlations with seedling composition $\left(R^{2}=0.13\right.$, $p=0.074$; Figure $3 b$, Table 3). Generally, we did not observe a clear relationship between declines in T. canadensis IV and change in composition (Figure 3c). However, we did observe less compositional change on plots with a greater basal area of R. maximum (Figure 3d).

\subsection{Sapling Species Composition}

NMDS for the sapling stratum with two axes reached a convergent solution after 70 runs with a final stress of 0.152 and a linear $R^{2}$ of 0.928 . Pre-HWA T. canadensis IV $\left(R^{2}=0.20, p=0.003\right), R A D$ $\left(R^{2}=0.32, p=0.001\right)$, and ecogroup $\left(R^{2}=0.30, p=0.001\right)$ were moderately correlated with sapling species composition (Figure $4 a$, Table 3$)$. Elevation $\left(R^{2}=0.10, p=0.048\right)$, and slope $\left(R^{2}=0.10, p=0.046\right)$ exhibited weak, but significant, correlations within the sapling ordination. 

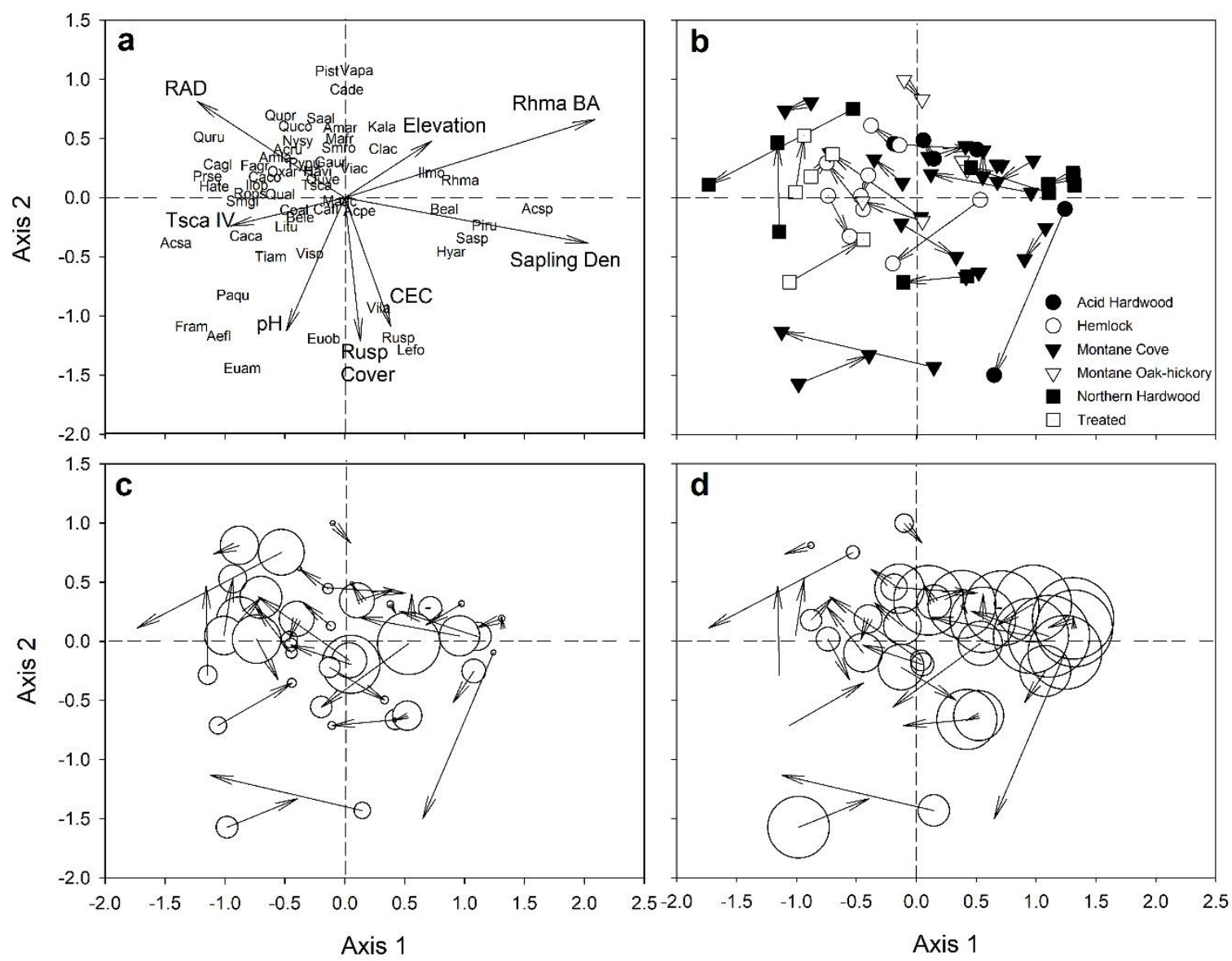

Figure 3. NMDS ordination of seedling species relative density: (a) Biplot of seedling species in 2017; significant $(\alpha=0.1$ ) environmental variables RAD (total potential incident radiation), Elevation, Rhma BA (R. maximum basal area), Sapling Den (total sapling density), CEC (cation exchange capacity), Rusp Cover (percent cover of Rubus spp.), pH (soil pH), and Tsca IV (pre-HWA overstory importance value of T. canadensis) are shown as vectors; (b) Successional vectors indicating change in composition from 2003 (pre-HWA) to 2017 (post-HWA) by ecogroup; (c) Successional vectors showing compositional change and bubble plot showing change in overstory T. canadensis IV between 2003 and 2017; and (d) Successional vectors showing compositional change and bubble plot showing relative density of $R$. maximum in 2003. Species abbreviations: Acpe $=$ Acer pensylvanicum L., Acru $=$ Acer rubrum, Acsa $=$ Acer saccharum, Acsp $=$ Acer spicatum, Aefl = Aesculus flava, Amar $=$ Amelanchier arborea (Michx. f.) Fernald, Amla = Amelanchier laevis Wiegand, Beal = Betula alleghaniensis, Bele = Betula lenta, Caca = Carpinus caroliniana Walter, Caco = Carya cordiformis (Wangenh.) K. Koch, Cade = Castanea dentata, Cafl = Calycanthus floridus L., Cagl = Carya glabra (Mill.) Sweet, Clac = Clethra acuminata Michx., Coal = Cornus alternifolia L. f., Euam = Euonymus americanus, Euob = Euonymus obovatus, Fagr = Fagus grandifolia Ehrh., Fram = Fraxinus americana, Guar = Gaylussacia ursina (M.A. Curtis) Torr. \& A. Gray ex A. Gray, Hate $=$ Halesia tetraptera, Havi = Hamamelis virginiana L., Hyar = Hydrangea arborescens L., Ilmo = Ilex montana, Ilop = Ilex opaca Aiton, Kala = Kalmia latifolia L., Lefo = Leucothoe fontanesiana, Litu = Liriodendron tulipifera L., Maac = Magnolia acuminata L., Mafr = Magnolia fraseri, Nysy = Nyssa sylvatica Marshall, Oxar = Oxydendrum arboreum (L.) DC., Paqu = Parthenocissus quinquefolia $($ L.) Planch., Piru = Picea rubens, Pist = Pinus strobus L., Prse = Prunus serotina, Pypu = Pyrularia pubera Michx., Qual = Quercus alba L., Quco = Quercus coccinea Münchh., Qupr = Quercus prinus, Quru = Quercus rubra, Quve = Quercus velutina Lam., Rhma $=$ Rhododendron maximum, Rops = Robinia pseudoacacia L., Rusp = Rubus spp. Saal = Sassafras albidum (Nutt.) Nees, Sasp = Sambucus spp. L., Smgl = Smilax glauca Walter, Smro = Smilax rotundifolia L., Tiam = Tilia americana L., Tsca = Tsuga canadensis, Vapa = Vaccinium pallidum Aiton, Viac = Viburnum acerifolium L., Vila = Viburnum lantanoides Michx., and Visp = Vitis spp. L. 

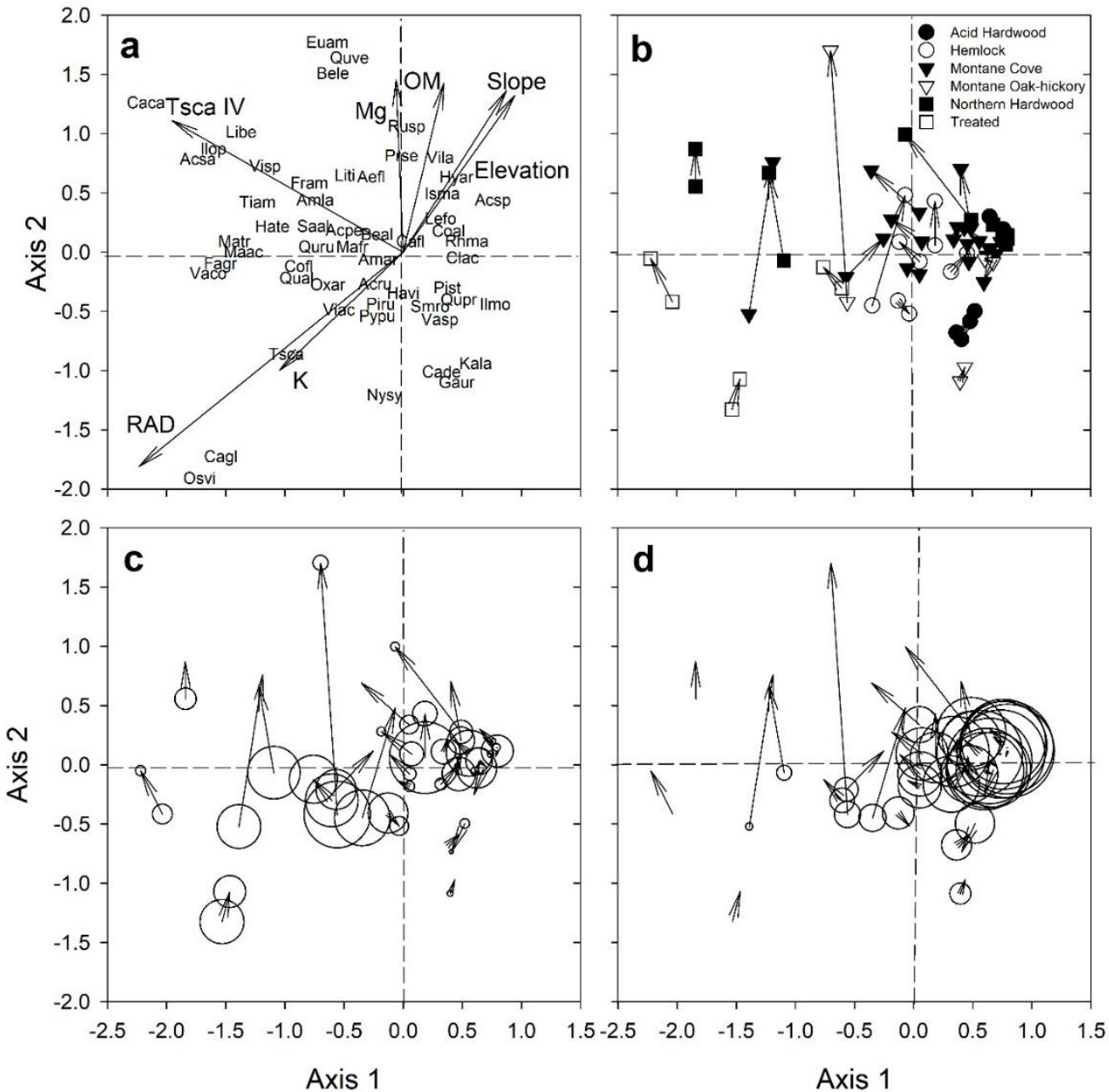

Figure 4. NMDS ordination of sapling species relative density: (a) Biplot of sapling strata species in 2017; significant ( $\alpha=0.1$ ) environmental variables $\mathrm{Mg}$ (ppm soil magnesium), OM (percent soil organic matter), Slope (percent slope), Elevation, K (ppm soil potassium), RAD (total potential incident radiation), and Tsca IV (pre-HWA overstory importance value of T. canadensis) are shown as vectors; (b) Successional vectors indicating change in composition from 2003 (pre-HWA) to 2017 (post-HWA) by ecogroup; (c) Successional vectors showing compositional change and bubble plot showing change in overstory T. canadensis IV between 2003 and 2017; and (d) Successional vectors showing compositional change and bubble plot showing relative density of R. maximum in 2003. Species abbreviations: Acpe = Acer pensylvanicum, Acru = Acer rubrum, Acsa = Acer saccharum, Acsp = Acer spicatum, Aefl = Aesculus flava, Amar = Amelanchier arbora, Amla = Amelanchier laevis, Beal = Betula alleghaniensis, Bele = Betula lenta, $\mathrm{Caca}=$ Carpinus caroliniana, $\mathrm{Caco}=$ Carya cordiformis, Cade $=$ Castanea dentata, Cafl $=$ Calycanthus floridus, Cagl = Carya glabra, Clac = Clethra acuminata, Coal $=$ Cornus alternifolia, Cofl = Cornus florida L., Euam $=$ Euonymus americanus, Euob = Euonymus obovatus, Fagr $=$ Fagus grandifolia, Fram $=$ Fraxinus americana, Guar = Gaylussacia ursina, Hate = Halesia tetraptera, Havi = Hamamelis virginiana, Hyar $=$ Hydrangea arborescens, Ilmo = Ilex montana, Ilop = Ilex opaca, Kala = Kalmia latifolia, Lefo = Leucothoe fontanesiana, Libe = Lindera benzoin (L.) Blume, Litu = Liriodendron tulipifera, Maac = Magnolia acuminata, Mafr = Magnolia fraseri, Matr = Magnolia tripetala L., Nysy = Nyssa sylvatica, Osvi = Ostrya virginiana (Mill.) K. Koch, Oxar = Oxydendrum arboreum, Paqu = Parthenocissus quinquefolia, Piru = Picea rubens, Pist $=$ Pinus strobus, Prse $=$ Prunus serotina, Pypu $=$ Pyrularia pubera, Qual $=$ Quercus alba, Quco $=$ Quercus coccinea, Qupr = Quercus prinus, Quru = Quercus rubra, Quve $=$ Quercus velutina, Rhma $=$ Rhododendron maximum, Rops = Robinia pseudoacacia, Rusp = Rubus spp. Saal = Sassafras albidum, Sasp = Sambucus spp., Smgl = Smilax glauca, Smro = Smilax rotundifolia, Tiam $=$ Tilia americana, Tsca $=$ Tsuga canadensis, Vaco = Vaccinium corymbosum L., Vapa = Vaccinium pallidum, Vasp = Vaccinium spp. L., Viac = Viburnum acerifolium, Vila $=$ Viburnum lantanoides, and Visp = Vitis spp. 
The mortality of $T$. canadensis drove shifts in sapling species composition, as evidenced by the large number of species associated with pre-HWA T. canadensis IV. Plots that experienced the greatest change in sapling stratum composition exhibited shifts in composition towards greater relative densities of early-mid seral tree species that were positively correlated with pre-HWA T. canadensis IV, including Liriodendron tulipifera (tulip poplar), P. serotina, B. lenta, and Quercus velutina (black oak), and shrub-layer species, such as Rubus spp., and Vaccinium corymbosum (highbush blueberry, that tend to increase in abundance with increasing light availability (Figure 4a). However, later seral species that often co-occur with T. canadensis, such as Acer saccharum, H. tetraptera, and Ilex opaca (American holly) also displayed strong positive correlations with pre-HWA T. canadensis IV (Figure 4a), suggesting persistence of advanced regeneration in the post-HWA understory.
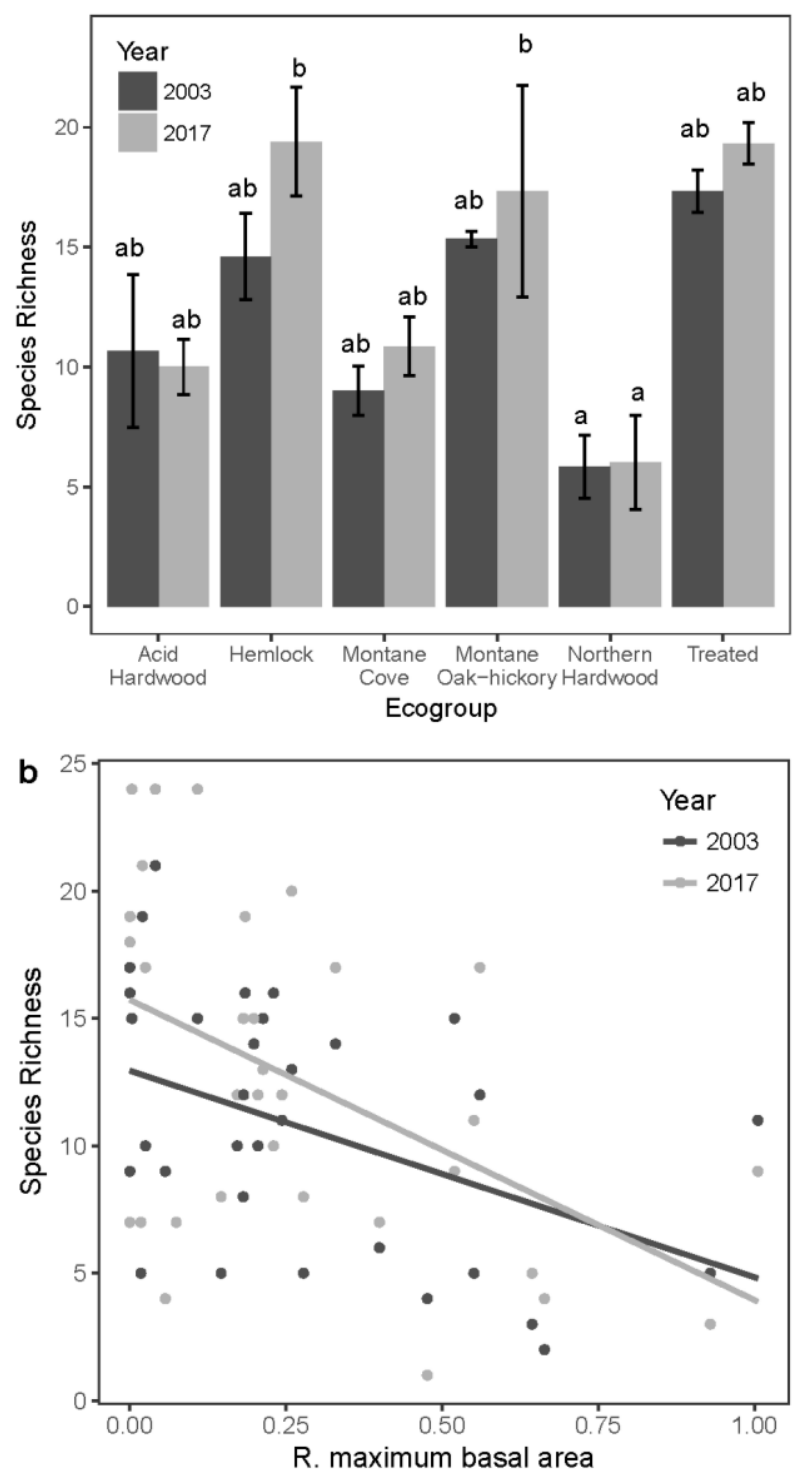

Figure 5. (a) Mean $( \pm \mathrm{SE})$ seedling species richness across ecogroups; (b) Seedling species richness as a function of $R$. maximum basal area. Superscripts indicate significant differences between year and ecogroups $(\alpha=0.05)$. 
Table 4. Richness (S), Evenness (E), and Shannon-Wiener Diversity $\left(\mathrm{H}^{\prime}\right.$; Mean $\left.\pm \mathrm{SE}\right)$ by strata across ecogroups and chemically treated plots.

\begin{tabular}{|c|c|c|c|c|c|c|c|c|c|c|c|c|}
\hline & \multicolumn{2}{|c|}{$\begin{array}{l}\text { Acid Hardwood } \\
\quad(n=3)\end{array}$} & \multicolumn{2}{|c|}{$\begin{array}{l}\text { Hemlock } \\
(n=5)\end{array}$} & \multicolumn{2}{|c|}{$\begin{array}{c}\text { Montane Cove } \\
(n=12)\end{array}$} & \multicolumn{2}{|c|}{$\begin{array}{l}\text { Montane Oak- Hickory } \\
(n=3)\end{array}$} & \multicolumn{2}{|c|}{$\begin{array}{l}\text { Northern Hardwood } \\
\quad(n=6)\end{array}$} & \multicolumn{2}{|c|}{$\begin{array}{l}\text { Treated } \\
(n=3)\end{array}$} \\
\hline & 2003 & 2017 & 2003 & 2017 & 2003 & 2017 & 2003 & 2017 & 2003 & 2017 & 2003 & 2017 \\
\hline \multicolumn{13}{|c|}{ Seedlings } \\
\hline $\mathrm{s}$ & $10.67 \pm 3.18$ & $10.00 \pm 1.15$ & $14.60 \pm 1.81$ & $19.40 \pm 2.27$ & $9.00 \pm 1.02$ & $10.85 \pm 1.22$ & $15.33 \pm 0.33$ & $17.33 \pm 4.41$ & $5.83 \pm 1.30$ & $6.00 \pm 2.00$ & $17.33 \pm 0.88$ & $19.33 \pm 0.88$ \\
\hline E & $0.73 \pm 0.10$ & $0.72 \pm 0.063$ & $0.67 \pm 0.035$ & $0.76 \pm 0.046$ & $0.63 \pm 0.047$ & $0.64 \pm 0.041$ & $0.75 \pm 0.029$ & $0.75 \pm 0.034$ & $0.57 \pm 0.073$ & $0.70 \pm 0.12$ & $0.83 \pm 0.040$ & $0.64 \pm 0.039$ \\
\hline $\mathrm{H}^{\prime}$ & $1.72 \pm 0.43$ & $1.67 \pm 0.22$ & $1.80 \pm 0.16$ & $2.25 \pm 0.18$ & $1.40 \pm 0.17$ & $1.47 \pm 0.13$ & $2.06 \pm 0.089$ & $2.09 \pm 0.30$ & $1.00 \pm 0.25$ & $1.10 \pm 0.35$ & $2.37 \pm 0.079$ & $1.90 \pm 0.088$ \\
\hline \multicolumn{13}{|c|}{ Saplings } \\
\hline $\mathrm{s}$ & & $11.67 \pm 0$. & $16.20 \pm 2.8$ & & $13.31 \pm 1.2$ & & $12.33 \pm 1.67$ & & $57 \pm 0.084$ & 39 & $19.67 \pm 2.03$ & 13.33 \\
\hline E & $0.42 \pm 0.10$ & $0.55 \pm 0.087$ & $0.62 \pm 0.025$ & $0.58 \pm 0.046$ & $46 \pm 0.055$ & $0.53 \pm 0.047$ & $0.46 \pm 0.092$ & $0.48 \pm 0.088$ & $0.34 \pm 0.11$ & $0.45 \pm 0.12$ & $0.57 \pm 0.11$ & $0.81 \pm 0.017$ \\
\hline $\mathrm{H}^{\prime}$ & $1.10 \pm 0.34$ & $1.37 \pm 0.25$ & $1.67 \pm 0.080$ & $1.70 \pm 0.19$ & $1.19 \pm 0.16$ & $1.37 \pm 0.15$ & $1.10 \pm 0.16$ & $1.37 \pm 0.42$ & $0.79 \pm 0.27$ & $1.05 \pm 0.33$ & $1.67 \pm 0.29$ & $2.08 \pm 0.10$ \\
\hline
\end{tabular}


According to successional vectors, composition changes in the sapling stratum were relatively unidirectional; however, the magnitudes of the changes differed among plots (Figure 3b). Plots with greater pre-HWA T. canadensis IV experienced greater changes in sapling species composition (Figure 3c). Acid cove plots, which had the lowest IV of T. canadensis prior to HWA (Figure 2) of any ecogroup, experienced the least compositional change of any ecogroup (Figure 4b). Plots with greater R. maximum BA experienced less change in the sapling layer than did plots with lower $R$. maximum BA (Figure $4 \mathrm{~d})$.

\subsection{Seedling Species Diversity}

Seedling species richness differed based on a three-way interaction of year, ecogroup, and R. maximum BA ( $F=2.70, p=0.049$, Figure 5a; Tables 4 and 5). Seedling species richness increased between 2003 to 2017 at low values of $R$. maximum BA and declined at high values of R. maximum BA (Figure 5b). Post-hoc comparisons between years and across ecogroups revealed that seedling species richness was significantly greater on hemlock plots in 2017 than northern hardwood plots in both $2003(p=0.014)$ and $2017(p=0.013)$, and was significantly greater on montane oak-hickory plots in 2017 than northern hardwood plots in both $2003(p=0.036)$ and $2017(p=0.033$; Figure 5a, Table 4). Changes between 2003 and 2017 in seedling species evenness varied among ecogroups depending on year $(\mathrm{F}=3.20, p=0.022$; Tables 4 and 5$)$; however, post-hoc comparisons did not reveal significant differences. Additionally, these results failed to meet the assumption of normality of error, and therefore results should be interpreted cautiously. Seedling species diversity differed among ecogroup ( $F=2.66, p=0.045$, Tables 4 and 5); however, post-hoc comparisons did not reveal any significant differences between ecogroups. Seedling species diversity also declined with increasing R. maximum $\mathrm{BA}$, however, the relationship was not significant $(\mathrm{F}=4.15, p=0.052)$.

\subsection{Sapling Species Diversity}

Sapling species diversity significantly increased between 2003 and $2017(\mathrm{~F}=12.99, p=0.001)$, but declined with increasing $R$. maximum $\mathrm{BA}(\mathrm{F}=34.54, p>0.001$; Tables 4 and 5). Sapling species richness differed based on a three-way interaction of year, ecogroup, and R. maximum $\mathrm{BA}(\mathrm{F}=6.86$, $p=0.0006$; Figure 6a,b; Tables 4 and 5). Sapling richness increased from 2003 to 2017 at low values of R. maximum BA and declined at high values of R. maximum BA (Figure 6b). Post-hoc comparisons between years and across ecogroups indicated that sapling species richness was significantly greater on hemlock plots in 2003 than northern hardwood plots in both 2003 and 2017 (2003: $p=0.033$, 2017: $p=0.033$; Figure 6a, Table 3). Sapling species evenness differed between 2003 and 2017; however, changes varied with ecogroup ( $F=3.87, p=0.009$, Figure $6 c$, Table 4$)$, and post-hoc comparisons revealed a significant increase in species evenness between 2003 and 2017 on treated plots $(p=0.006)$. Sapling species evenness declined with increasing R. maximum BA $(F=39.69, p<0.001$; Table 4). 

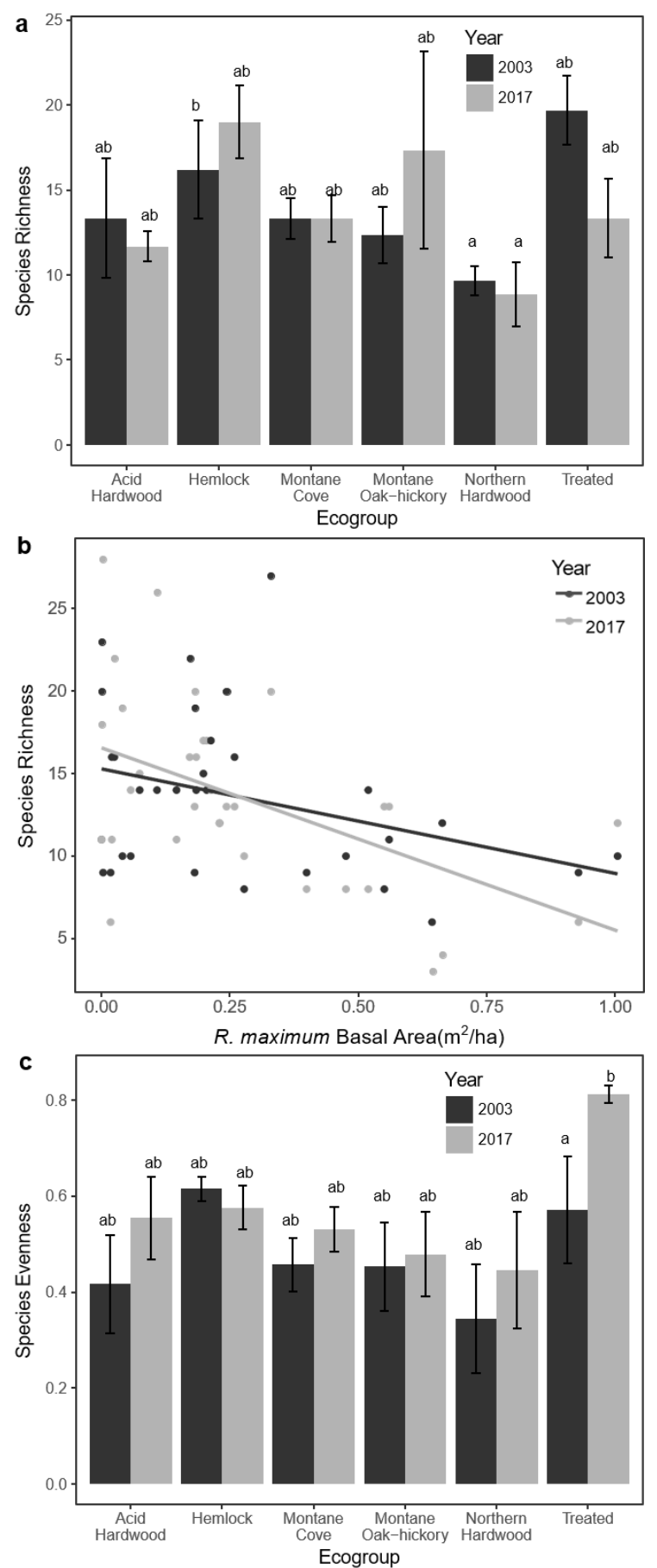

Figure 6. (a) Mean $( \pm$ SE) sapling species richness across ecogroups. Superscripts indicate significant differences between year and ecogroups $(\alpha=0.05)$; (b) Sapling species richness as a function of $R$. maximum BA; (c) Mean ( $\pm \mathrm{SE})$ sapling species evenness across ecogroups. Superscripts indicate significant differences between year and ecogroups $(\alpha=0.05)$. 
Table 5. General linear mixed model ANOVA results for diversity metrics across both woody strata.

\begin{tabular}{|c|c|c|c|c|c|c|c|c|c|c|}
\hline & \multicolumn{4}{|c|}{$\begin{array}{c}\text { Shannon-Weaver } \\
\text { Diversity }\end{array}$} & \multicolumn{3}{|c|}{ Species Richness } & \multicolumn{3}{|c|}{ Species Evenness } \\
\hline & df & MS & F & $p$ & MS & F & $p$ & MS & F & $p$ \\
\hline \multicolumn{11}{|c|}{ Seedlings } \\
\hline Year & 1 & 0.013 & 0.08 & 0.78 & 0.01 & 0.05 & 0.82 & 0.005 & 0.002 & 0.97 \\
\hline Ecogroup & 5 & 0.44 & 2.66 & 0.045 & 0.75 & 4.63 & 0.005 & 0.20 & 0.75 & 0.59 \\
\hline R. maximum $\mathrm{BA}$ & 1 & 0.69 & 4.15 & 0.052 & 0.01 & 0.08 & 0.78 & - & - & - \\
\hline Year $\times$ Ecogroup & 5 & 0.41 & 2.51 & 0.055 & 0.14 & 0.85 & 0.53 & 0.86 & 3.20 & 0.022 \\
\hline Year $\times R$. maximum & & & & & & & & & & \\
\hline BA & 1 & - & - & - & 0.06 & 0.34 & 0.56 & - & - & - \\
\hline Ecogroup $\times R$. maximum & & & & & & & & & & \\
\hline $\begin{array}{l}\text { BA } \\
\text { Year } x\end{array}$ & 5 & - & - & - & 0.22 & 1.34 & 0.29 & - & - & - \\
\hline Ecogroup $\times$ & & & & & & & & & & \\
\hline R. maximum BA & 5 & - & - & - & 0.44 & 2.70 & 0.049 & - & - & - \\
\hline \multicolumn{11}{|c|}{ Saplings } \\
\hline Year & 1 & 1.92 & 12.99 & 0.001 & 0.028 & 0.11 & 0.74 & 2.52 & 22.75 & $<0.001$ \\
\hline Ecogroup & 5 & 0.24 & 1.61 & 0.19 & 0.81 & 3.23 & 0.026 & 0.11 & 1.01 & 0.43 \\
\hline R. maximum $\mathrm{BA}$ & 1 & 5.08 & 34.54 & $<0.001$ & 0.51 & 2.01 & 0.17 & 4.39 & 39.69 & $<0.001$ \\
\hline Year $\times$ Ecogroup & 5 & 0.093 & 0.63 & 0.68 & 0.19 & 0.77 & 0.58 & 0.43 & 3.87 & 0.009 \\
\hline Year $\times R$. maximum & & & & & & & & & & \\
\hline BA & 1 & - & - & - & 0.015 & 0.058 & 0.81 & - & - & - \\
\hline Ecogroup $\times R$. maximum & & & & & & & & & & \\
\hline BA & 5 & - & - & - & 0.24 & 0.95 & 0.47 & - & - & - \\
\hline Year $x$ & & & & & & & & & & \\
\hline Ecogroup $\times R$. maximum & & & & & & & & & & \\
\hline BA & 5 & - & - & - & 1.73 & 6.86 & 0.0006 & - & - & - \\
\hline
\end{tabular}

\section{Discussion}

Over 15 years have passed since HWA was first discovered within Great Smoky Mountains National Park [26]. While treated T. canadensis trees survive within conservation areas, we observed few surviving trees outside of these areas, and those that were alive showed obvious signs of decline. Simulations predict that only two percent of initial T. canadensis BA will survive HWA, and the hemlock forest type will be effectively lost within 20 years after the introduction of HWA to the central Appalachians [28]. The near complete mortality of T. canadensis we observed supports this prediction in the southern Appalachians as well.

Prior to the arrival of HWA, T. canadensis was a dominant or co-dominant species in four forest ecogroups across the park (Montane Alluvial Forests, Cove Forests, Hemlock Forests, and Spruce-Fir Forests; [32]), and the loss of this foundation species has begun to alter forest communities. When initially resampled in 2008/2009, the health of T. canadensis trees had declined across all ecogroups, however, changes across the seedling and sapling strata of the forest were not yet evident $[27,29]$. Given the extended time that has passed since invasion, near complete mortality of $T$. canadensis trees, and resulting changes in the microclimate $[21,23,29,30,49-51]$, we were able to document changes occurring in the forest communities where T. canadensis was an important component.

Plots with lower BA of R. maximum and greater pre-HWA T. canadensis IV experienced greater compositional change between sampling intervals as predicted, supporting the hypothesis that the ericaceous shrub R. maximum buffers change in forest understories ([27,30,52], Figures 2 and 3$)$. In the sapling stratum, these changes were largely unidirectional, and ecogroups tended to converge in composition. Typically, hardwood species regeneration is low beneath dense thickets of R. maximum due to the effects of the shrub on light levels, soil nutrients, water availability, microclimate, and the soil seed bank [31,53-57]. Our results demonstrate this trend across both woody strata, as measures of diversity tended to be lower on plots with greater BA of R. maximum (Figures 4-6, Table 3). Additionally, few species in the seedling strata were found in these areas (Figure 2a,b).

Rhododendron maximum typically occurs along streams in the southern Appalachians, and has been observed to spread following canopy disturbances. Several studies have documented the expansion of R. maximum following the loss of $C$. dentata in the 1930s as a result of chestnut blight and large-scale 
logging $[31,55,58,59]$. While we did not document increased BA of $R$. maximum across our study area as a whole, plots with less than $0.3 \mathrm{~m}^{2} /$ ha $R$. maximum in 2003 saw a $160 \%$ increase in total $R$. maximum percent cover in the herbaceous layer $(<0.5 \mathrm{~m})$ and a mean increase of $86 \%$ in cover in the understory (0.5-4.99 m above the ground; Great Smoky Mountains National Park unpublished data). Additionally, increased growth of R. maximum was documented in riparian forests of the Coweeta Basin of the southern Appalachians following HWA-induced T. canadensis mortality [30]. The disturbance-driven expansion of R. maximum may suppress woody regeneration and cause the conversion of some forests into treeless thickets of R. maximum, a condition similar to ericaceous-shrub-dominated heath balds that occur at higher elevations $[27,30,31]$. Quantifying $R$. maximum is challenging due to its branching form and extreme density, and further study using techniques such as remote sensing may be able to provide greater insight into possible expansion of R. maximum in GSMNP following HWA infestation. Where R. maximum did not form dense thickets, changes in the microclimate following HWA infestation, particularly during leaf-off periods for deciduous species, tend to be more pronounced [30]. In our study, plots with lower R. maximum BA tended to exhibit greater community change in the seedling and sapling strata, with composition shifting towards early seral deciduous species (Figure $3 b, d$ and Figure $4 b, d)$.

In our ordination analyses, the relative densities of many deciduous species were strongly correlated with a topographically derived variable (total potential incident radiation), as well as several edaphic variables ( $\mathrm{pH}, \mathrm{CEC}$, ppm $\mathrm{K}, \mathrm{ppm} \mathrm{Mg}$, and percent soil organic matter). This supports our hypotheses that these variables underlay the distribution of woody regeneration on sites where R. maximum is less dominant and mortality of T. canadensis increased the availability of light and other resources. Topographic variables are often strongly related to the distribution of woody species regeneration following overstory disturbance in forest regions without a pervasive shrub layer [60-62]. In addition, an ordination analysis by Elliott and Knoepp [63] found that edaphic variables, including $\mathrm{CEC}, \mathrm{ppm} \mathrm{Mg}$, and ppm $\mathrm{K}$, were strongly correlated with the distribution of woody species regeneration after harvest operations reduced overstory cover and the abundance of the dominant shrub species. In our study, fewer species were associated with edaphic variables than with vegetation variables. However, A. flava, E. americanus, and Rubus spp. were associated with edaphic variables in both the seedling and sapling strata, suggesting that edaphic conditions may favor certain species during post-HWA succession.

While understory woody species composition (seedling and sapling strata) was strongly correlated with pre-HWA T. canadensis IV and R. maximum BA, and shifts in understory composition appear to be driven by them, the loss T. canadensis in the overstory did not result in corresponding large changes in the importance of other overstory species. It is likely that large-scale changes in composition have not yet reached the overstory and changes more strongly correlated with pre-HWA T. canadensis IV and R. maximum BA will occur as stems currently in the sapling layer and subcanopy recruit into the overstory. Individual species, however, including B. alleghaniensis, B. lenta, and A. rubrum, did exhibit increased overstory importance, and likely exhibited lateral growth of co-dominant and intermediate trees, as was predicted by earlier work [27] and observed in subsequent studies ([30], Table 2). Although composition was variable across ecogroups, these three hardwood species generally increased in abundance in the sapling layers of our plots following T. canadensis mortality. In areas that lack a dense R. maximum understory, therefore, we predict that overstory composition will continue to shift towards mixed hardwood composition, similar to areas infested earlier by HWA, and B. alleghaniensis, B. lenta, and $A$. rubrum will continue to increase in importance across ecogroups $[24,30]$.

Both field and modeling studies have demonstrated that successional pathways resulting from the loss of $T$. canadensis are determined by multiple biotic and abiotic factors, making them difficult to predict $[16,30,52,64]$. Continued monitoring, therefore, is necessary to understand how these forests will continue to change with the functional extinction of T. canadensis. The species that ultimately fill the compositional voids created by the loss T. canadensis will, in turn, influence important ecological processes, such as nutrient cycling, microclimate control, and water use [50,52,56,65-67]. 
While areas with dense $R$. maximum populations may see less change, areas where hardwood species become dominant will likely see increased rates of nitrogen cycling rates and decreased rates of transpiration [49,68-71].

HWA will likely not be the last invasive insect or pathogen to reach the southern Appalachian Mountains $[4,8]$. While chemical treatment and biocontrol options are available for many invasive species such as HWA, large forested areas, such as GSMNP, are unable to rely on their widespread use, making changes to forest communities inevitable. Understanding how forest communities change in response to the loss of $T$. canadensis will help managers better predict future changes driven by the next invasive threat, as well as understand how wide-spread synchronous tree mortality and gap formation may affect successional patterns in the southern Appalachian Mountains.

Author Contributions: Conceptualization, M.L.M., E.J.H., and M.A.J.; formal analysis, M.L.M.; investigation, M.L.M., E.J.H., and M.A.J.; resources, M.A.J.; data curation, M.L.M.; writing-original draft preparation, M.L.M. and M.A.J.; writing-review and editing, M.L.M., E.J.H. and M.A.J., supervision, M.L.M. and M.A.J.; project administration, M.A.J.; funding acquisition, M.A.J.

Funding: This work was supported with funding from Great Smoky Mountains National Park, a Carlos C. Campbell Memorial Research Fellowship awarded by the Great Smoky Mountains Conservation Association, and the USDA McIntire-Stennis Cooperative Forestry Program (Project IND011533MS).

Acknowledgments: We thank Laura Estrada and Pierce Holloway for their assistance with fieldwork. Troy Evans, Tom Remaley, Paul Super, Kendra Straub, Becky Nichols, and Tom Colson provided valuable input and assistance. We also thank two anonymous reviewers for their helpful comments.

Conflicts of Interest: The authors declare no conflict of interest.

\section{References}

1. McCullough, D.G.; Work, T.T.; Cavey, J.F.; Liebhold, A.M.; Marshall, D. Interceptions of nonindigenous plant pests at US ports of entry and border crossings over a 17-year period. Biol. Invasions 2006, 8, 611-630. [CrossRef]

2. Westphal, M.I.; Browne, M.; MacKinnon, K.; Noble, I. The link between international trade and the global distribution of invasive alien species. Biol. Invasions 2008, 10, 391-398. [CrossRef]

3. Work, T.T.; McCullough, D.G.; Cavey, J.F.; Komsa, R. Arrival rate of nonindigenous insect species into the United States through foreign trade. Biol. Invasions 2005, 7, 323-332. [CrossRef]

4. Sala, O.E.; Chapin, F.S., III; Armesto, J.J.; Berlow, E.; Bloomfield, J.; Dirzo, R.; Huber-Sanwald, E.; Huenneke, L.F.; Jackson, R.B.; Kinzig, A.; et al. Global biodiversity scenarios for the year 2100. Science 2000, 287, 1700-1774. [CrossRef]

5. Ellison, A.M.; Bank, M.S.; Clinton, B.D.; Colburn, E.A.; Elliott, K.; Ford, C.R.; Foster, D.R.; Kloeppel, B.D.; Knoepp, J.D.; Lovett, G.M.; et al. Loss of foundation species: Consequences for the structure and dynamics of forested ecosystems. Front. Ecol. Environ. 2005, 3, 479-486. [CrossRef]

6. Gandhi, K.J.K.; Herms, D.A. Direct and indirect effects of alien insect herbivores on ecological processes and interactions in forests of eastern North America. Biol. Invasions 2010, 12, 389-405. [CrossRef]

7. Lovett, G.M.; Canham, C.D.; Arthur, M.A.; Weathers, K.C.; Fitzhugh, R.D. Forest ecosystem responses to exotic pests and pathogens in eastern North America. BioScience 2006, 56, 395-405. [CrossRef]

8. Aukema, J.E.; McCullough, D.G.; Von Holle, B.; Liebhold, A.M.; Britton, K.; Frankel, S.J. Historical accumulation of nonindigenous forest pests in the continental United States. BioScience 2010, 60, 886-897. [CrossRef]

9. Kenis, M.; Auger-Rozenburg, M.; Roques, A.; Timms, L.; Péré, C.; Cock, M.J.W.; Settele, J.; Augustin, S.; Lopez-Vaamonde, C. Ecological effects of invasion alien insects. Biol. Invasions 2009, 11, 21-45. [CrossRef]

10. McCormick, J.F.; Platt, R.B. Recovery of an Appalachian forest following the chestnut blight or Catherine Keever-You were right! Am. Midl. Nat. 1980, 104, 264-273. [CrossRef]

11. Woods, F.W.; Shanks, R.E. Natural replacement of chestnut by other species in the Great Smoky Mountains National Park. Ecology 1959, 40, 349-361. [CrossRef]

12. Keever, C. Present composition of some stands of the former oak-chestnut forest in the southern Blue Ridge Mountains. Ecology 1953, 34, 44-54. [CrossRef] 
13. McClure, M.S. Density-dependent feedback and population cycles in Adelges tsugae (Homoptera: Adelgidae) on Tsuga canadensis. Environ. Entomol. 1991, 20, 258-264. [CrossRef]

14. Cheah, C.; Montgomery, M.E.; Salom, S.; Parker, B.L.; Costa, S.; Skinner, M. Biological Control of Hemlock Woolly Adelgid; Reardon, R., Onken, B., Eds.; FHTET, 2004-04; USDA Forest Service, Forest Health Technology Enterprise Team: Morgantown, WV, USA, 2004.

15. Young, R.F.; Shields, K.S.; Berlyn, G.P. Hemlock woolly adelgid (Homoptera: Adelgidae): Stylet bundle insertion and feeding sites. Ann. Entom. Soc. Am. 1995, 88, 827-835. [CrossRef]

16. Eschtruth, A.K.; Evans, R.A.; Battles, J.J. Patterns and predictors of survival in Tsuga canadensis populations infested by the exotic pest Adelges tsugae: 20 years of monitoring. For. Ecol. Manag. 2013, 305, 195-203. [CrossRef]

17. Godman, R.M.; Lancaster, K. Tsuga canadensis. In Silvics of North America: Conifers; Burns, R.M., Honkala, B.H., Eds.; USDA Forest Service, Handbook; USDA Forest Service: Washington, DC, USA, 1990; Volume 1, pp. 604-612.

18. Holzmueller, E.J.; Jose, S.; Jenkins, M.A. The relationship between fire history and an exotic fungal disease in a deciduous forest. Oecologia 2008, 155, 347-356. [CrossRef] [PubMed]

19. Van Lear, D.H.; Vandermast, D.B.; Rivers, C.T.; Baker, T.T.; Hedman, C.W.; Clinton, D.B.; Waldrop, T.A. American Chestnut, Rhododendron, and the Future of Appalachian Cove Forests; Outcalt, K.W., Ed.; USDA Forest Service, Southern Research Station: Ashville, NC, USA, 2002; pp. 214-220.

20. Toenies, M.J.; Miller, D.A.; Marshall, M.R.; Stauffer, G.E. Shifts in vegetation and avian community structure following the decline of a foundational forest species, the eastern hemlock. Condor Ornithol. Appl. 2018, 120, 489-506. [CrossRef]

21. Eschtruth, A.K.; Cleavitt, N.L.; Battles, J.J.; Evans, R.A.; Fahey, T.J. Vegetation dynamics in declining eastern hemlock stands: 9 years of forest response to hemlock woolly adelgid infestation. Can. J. For. Res. 2006, 36, 1435-1450. [CrossRef]

22. Foster, D.R.; Zebryk, T.M. Long-term vegetation dynamics and disturbance history of a Tsuga-dominated forest in New England. Ecology 1993, 74, 982-998. [CrossRef]

23. Orwig, D.A.; Foster, D.R. Forest response to the introduced hemlock woolly adelgid in southern New England, USA. J. Torrey Bot. Soc. 1998, 125, 60-73. [CrossRef]

24. Small, M.J.; Small, C.J.; Dreyer, G.D. Changes in a hemlock-dominated forest following woolly adelgid infestation in southern New England. J. Torrey Bot. Soc. 2005, 132, 458-470. [CrossRef]

25. Orwig, D.A.; Plotkin, A.A.B.; Davidson, E.A.; Lux, H.; Savage, K.E.; Ellison, A.M. Foundation species loss affects vegetation structure more than ecosystem function in a northeastern USA forest. PeerJ 2013, 1, 1-29. [CrossRef] [PubMed]

26. Johnson, K.; Remaley, T.; Taylor, G. Managing Hemlock Woolly Adelgid at Great Smoky Mountains National Park: Situation and Response; Onken, B., Reardon, R., Eds.; FHTET-2008-01; USDA Forest Service, Forest Health Technology Enterprise Team: Morgantown, WV, USA, 2008; pp. 62-69.

27. Krapfl, K.J.; Holzmueller, E.J.; Jenkins, M.A. Early impacts of hemlock woolly adelgid in Tsuga canadensis forest communities of the southern Appalachian Mountains. J. Torrey Bot. Soc. 2011, 138, 93-106. [CrossRef]

28. Spaulding, H.L.; Rieske, L.K. The aftermath of an invasion: Structure and composition of central Appalachian hemlock forests following establishment of the hemlock woolly adelgid, Adelges tsugae. Biol. Invasions 2010, 12, 3135-3143. [CrossRef]

29. Krapfl, K.J.; Holzmueller, E.J.; Jenkins, M.A. Understory composition of five Tsuga canadensis associated forest communities in Great Smoky Mountains National Park. Nat. Areas J. 2012, 32, 260-269. [CrossRef]

30. Ford, C.R.; Elliot, K.J.; Clinton, B.D.; Kloeppel, B.D.; Vose, J.M. Forest dynamics following eastern hemlock mortality in the southern Appalachians. Oikos 2012, 121, 523-536. [CrossRef]

31. Elliot, K.J.; Vose, J.M. Age and distribution of an evergreen clonal shrub in Coweeta Basin: Rhododendron maximum L. J. Torrey Bot. Soc. 2012, 139, 149-166. [CrossRef]

32. Jenkins, M.A. Vegetation communities of Great Smoky Mountains National Park. Southeast. Nat. 2007, 6, 35-56. [CrossRef]

33. Southworth, S.; Schultz, A.; Denenny, D. Generalized Geologic Map of Bedrock Lithologies and Surficial Deposits in the Great Smoky Mountains National Park Region, Tennessee and North Carolina; Open-File Report 2004-1410, Version 1.0; U.S. Geological Survey: Reston, VA, USA, 2005.

34. Whittaker, R.H. Vegetation of the Great Smoky Mountains. Ecol. Monogr. 1956, 26, 1-80. [CrossRef] 
35. White, R.D.; Patterson, K.D.; Weakley, A.; Ulrey, C.J.; Drake, J. Vegetation Classification of Great Smoky Mountains National Park; Report Submitted to BRDNPS Vegetation Mapping Program; NatureServe: Durham, NC, USA, 2003.

36. Johnson, K.; Taylor, G.; Remaley, T. Managing hemlock woolly adelgid and balsam woolly adelgid at Great Smoky Mountains National Park. In Proceedings of the Third Symposium on Hemlock Woolly Adelgid in the Eastern United States, Asheville, NC, USA, 1-3 February 2005.

37. Abella, S.R. Impacts and management of hemlock woolly adelgid in national parks of the eastern United States. Southeast. Nat. 2014, 13, 16-45.

38. Webster, J. Management of hemlock woolly adelgid in Great Smoky Mountains National Park. In Proceedings of the Fifth Symposium on Hemlock Woolly Adelgid in the Eastern United States, Asheville, NC, USA, 17-19 August 2010.

39. Jenkins, M.A. Great Smoky Mountains National Park: Vegetation Monitoring Protocol; National Park Service, Inventory and Monitoring Program, Great Smoky Mountains National Park: Gatlinburg, TN, USA, 2008.

40. Mehlich, A. Mehlich 3 soil test extractant: A modification of Mehlich 2 extractant. Commun. Soil Sci. Plant. Anal. 1984, 15, 1409-1416. [CrossRef]

41. McCune, B.; Grace, J.B. Analysis of Ecological Communities, 3rd ed.; MjM Software Design: Glaneden Beach, OR, USA, 2002.

42. R Development Core Team. R: A Language and Environment for Statistical Computing; R Foundation for Statistical Computing: Vienna, Austria, 2016.

43. McCune, B.; Keon, D. Equations for potential annual direct incident radiation and heat load. J. Veg. Sci. 2002, 13, 603-606. [CrossRef]

44. Bates, D.; Maechler, M.; Bolker, B.; Walker, S. Fitting linear mixed-effects models using lme4. J. Stat. Soft. 2015, 67, 1-48. [CrossRef]

45. Kuznetsova, A.; Brockhoff, P.B.; Christensen, R.H.B. LmerTest package: Tests in linear mixed effects models. J. Stat. Soft. 2017, 82, 1-26. [CrossRef]

46. Laird, N.M.; Ware, J.H. Random-effects models for longitudinal data. Biometrics 1982, 38, 963-974. [CrossRef] [PubMed]

47. Oksanen, J.; Blanchet, F.G.; Friendly, M.; Kindt, R.; Legendre, P.; Mcglinn, D.; Minchin, P.R.; O’Hara, R.B.; Simpson, G.L.; Solymos, P.; et al. Vegan: Community Ecology Package. R Package Version 2.4-5. 2017. Available online: https://CRAN.R-project.org/package=vegan (accessed on 3 October 2017).

48. Leth, R.V. Least-squares means: The R package lsmeans. J. Stat. Soft. 2016, 69, 1-33.

49. Jenkins, J.C.; Aber, J.D.; Canham, C.D. Hemlock woolly adelgid impacts on community structure and N cycling rates in eastern hemlock forests. Can. J. Res. 1999, 29, 630-645. [CrossRef]

50. Lustenhouwer, M.N.; Nicoll, L.; Ellison, A.M. Microclimate effects of the loss of a foundation species from New England forests. Ecosphere 2012, 3, 1-16. [CrossRef]

51. Orwig, D.A.; Cobb, R.C.; D'Amato, A.W.; Kizlinski, M.L.; Foster, D.R. Multi-year ecosystem response to hemlock woolly adelgid infestation in southern New England forests. Can. J. Res. 2008, 38, 834-843. [CrossRef]

52. Vose, J.M.; Wear, D.N.; Mayfield, A.E., III; Nelson, C.D. Hemlock woolly adelgid in the southern Appalachians: Control strategies, ecological impacts, and potential management responses. For. Ecol. Manag. 2013, 291, 209-219. [CrossRef]

53. Cofer, T.M.; Elliott, K.J.; Bush, J.K.; Miniat, C.F. Rhododendron maximum impacts seed bank composition and richness following Tsuga canadensis loss in riparian forests. Ecosphere 2018, 9, e02204. [CrossRef]

54. Nilsen, E.T.; Clinton, B.D.; Lei, T.T.; Miller, O.K.; Semones, S.W.; Walker, J.F. Rhododendron maximum L. (Ericaceae) reduce the availability of resources above and belowground for canopy tree seedlings? Am. Midl. Nat. 2001, 145, 325-343. [CrossRef]

55. Phillips, D.L.; Murdy, W.H. Effects of rhododendron (Rhododendron maximum L.) on regeneration of southern Appalachian hardwoods. For. Sci. 1985, 31, 226-233.

56. Roberts, S.W.; Tankersley, R., Jr.; Orvis, K.H. Assessing the potential impacts to riparian ecosystems resulting from hemlock mortality in Great Smoky Mountains National Park. Environ. Manag. 2009, 44, 335-345. [CrossRef]

57. Wurzburger, N.; Hendrick, R.L. Rhododendron thickets alter N cycling and soil extracellular enzyme activities in southern Appalachian hardwood forests. Pedobiologia 2007, 50, 563-576. [CrossRef]

58. McGee, C.E.; Smith, R.C. Undisturbed rhododendron thickets are not spreading. J. For. 1967, 65, $334-335$. 
59. Plocher, A.E.; Carvell, K.L. Population dynamics of rosebay rhododendron thickets in the southern Appalachians. Bull. Torrey Bot. Club 1987, 114, 121-126. [CrossRef]

60. Goebel, P.C.; Hix, D.M. Changes in the composition and structure of mixed-oak, second-growth forest ecosystems during the understory reinitiation stage of stand development. Ecoscience 1997, 4, 327-339. [CrossRef]

61. Jenkins, M.A.; Parker, G.R. Composition and diversity of woody vegetation in silvicultural openings of southern Indiana forests. For. Ecol. Manag. 1998, 109, 57-74. [CrossRef]

62. Pallardy, S.G. Vegetation analysis, environmental relationships, and potential successional trends in Missouri Forest Ecosystem Project. In Proceedings of the 10th Central Hardwood Forest Conference, Morgantown, WV, USA, 5-8 March 1995.

63. Elliott, K.J.; Knoepp, J.D. The effects of three regeneration harvest methods on plant diversity and soil characteristics in the southern Appalachians. For. Ecol. Manag. 2005, 211, 296-317. [CrossRef]

64. Case, B.S.; Buckley, H.L.; Barker-Plotkin, A.A.; Orwig, D.A.; Ellison, A.M. When a foundation crumbles: Forecasting forest dynamics following the decline of the foundation species Tsuga canadensis. Ecosphere 2017, 8, e01893. [CrossRef]

65. Boettcher, S.E.; Kalisz, P.J. Single-tree influence on soil properties in the mountains of eastern Kentucky. Ecology 1990, 71, 1365-1372. [CrossRef]

66. Finzi, A.C.; van Breemen, N.; Canham, C.D. Canopy tree-soil interactions within temperate forests: Species effects on soil carbon and nitrogen. Ecol. Appl. 1998, 8, 440-446.

67. Finzi, A.C.; Canham, C.D.; van Breemen, N. Canopy tree-soil interactions within temperate forests: Species effects on $\mathrm{pH}$ and cations. Ecol. Appl. 1998, 8, 447-454.

68. Brantley, S.; Ford, C.R.; Vose, J.M. Future species composition will affect forest water use after loss of eastern hemlock. Ecol. Appl. 2013, 23, 777-790. [CrossRef]

69. Ford, C.R.; Vose, J.M. Tsuga canadensis (L.) Carr. mortality will impact hydrologic processes in southern Appalachian forest ecosystems. Ecol. Appl. 2007, 17, 1156-1167. [CrossRef]

70. Knoepp, J.D.; Vose, J.M.; Clinton, B.D.; Hunter, M.D. Hemlock infestation and mortality: Impacts on nutrient pools and cycling in Appalachian forests. Soil Sci. Soc. Am. J. 2011, 75, 1935-1945. [CrossRef]

71. Yorks, T.E.; Leopold, D.J.; Raynal, D.J. Effects of Tsuga canadensis mortality on soil water chemistry and understory vegetation: Possible consequences of an invasive herbivore. Can. J. For. Res. 2003, 33, 1525-1537. [CrossRef]

(C) 2019 by the authors. Licensee MDPI, Basel, Switzerland. This article is an open access article distributed under the terms and conditions of the Creative Commons Attribution (CC BY) license (http://creativecommons.org/licenses/by/4.0/). 